\title{
TO THE LAST TREE STANDING? \\ Ottoman-Hungarian Wars and Forests in Transdanubia ${ }^{1}$
}

\author{
ANDrás VADas ${ }^{2}$ \\ Hungarian Archaeology Vol. 9 (2020), Issue 2, pp. 49-57, https://doi.org/10.36338/ha.2020.2.6
}

Historical and archaeological research into Ottoman-period fortifications started in Hungary almost a century ago. In general, these fortifications, built mainly of wood and earth, received considerably less scholarly attention than the ones built of stone. The study of these wooden buildings received impetus in the past few years as new research techniques appeared, such as dendrochronology and dendroclimatology, and new research perspectives, such as environmental history, became emphatic. The question of historical forest cover, that is, the ratio of forests that had been lost in different time periods, became a hot topic again. Historiography traditionally devoted special attention to the period of the Ottoman-Turkish wars. In this paper I discuss how the wood exploitation related to the Ottoman wars can be estimated and how the changes in the forest cover in the area affected by the war can be assessed.

The political changes of the 16th century fundamentally transformed the spatial structure and economy of the Carpathian Basin, most of which belonged to the Kingdom of Hungary in the Middle Ages. The gradual expansion of the Ottoman Empire to the Great Hungarian Plain and to Transdanubia in the decades following the Battle of Mohács (1526) largely affected the settlement pattern in the area. The number of settlements decreased, leading to the formation of large market towns in Ottoman Hungary. Humanists, poets and authors saw or, at least, described the Middle Ages as a period of wealth and fertility as opposed to their own time, about which they either remained silent or emphasized a total devastation of the land. This narrative and view of the events and processes persisted for a long time. Research in the 20th-century interwar period still saw the 16th-17th centuries as a period when the rich lands of Hungary were destroyed. From the perspective of this paper, the most important statement of the research in this period is that the Ottomans were to blame for the destruction of the "traditional" landscape in the Carpathian Basin. The narrative according to which the Carpathian Basin, with its forests and rich pastures, became a wasteland, and villages lost their populations because of Ottoman plunders, received some criticism already in the interwar period (VÁGI 1934; WEIDLEIN 1935), as well as in the last half a century by botanists, ecologists, historians, as well as archaeologists. As a result, the view of Early Modern farming and ecological changes became much more nuanced. It has increasingly been interpreted more as an economic transformation that was necessitated by the Ottoman conquest but had started well before their arrival, rather than a crisis caused by a change in political relations. However, the process is still often being interpreted as a decline, partly because of the political changes in the period, and - in more recent scholarship - because of the changes in climate that supposedly took place in the Early Modern period. This is partly because the Ottoman period coincides with the period of the Little Ice Age, which brought a colder climate in Western Europe, contributing to significant economic stress there. Key aspects of this narrative of decline - especially in the context of the Ottoman-Hungarian frontier and the Great Hungarian Plain - are the loss of forests and the extension of marshlands in the low-lying areas of the central basin due to the abandonment of water systems. In the existing scholarly literature, the loss of woodland appears directly in the context of the Ottoman-Hungarian frontier zone. In this paper, this aspect will be in the focus. My aim is to gain a better understanding what role the Ottoman presence, the lasting wars, and the construction of numerous wood and earth fortifications may have played in shaping the forest cover in the Carpathian Basin, the frontier area, and the landscape in general.

\footnotetext{
This research was supported by the ÚNKP-19-4 New National Excellence Program of the Ministry for Innovation and Technology.

2 Eötvös Loránd University, Faculty of Humanities, Department of Medieval History. E-mail: vadas.andras@btk.elte.hu
} 
András Vadas $\bullet$ To the Last Tree Standing? Ottoman-Hungarian Wars and Forests in Transdanubia

\section{WOODLAND EXPLOITATION IN THE EARLY MODERN PERIOD}

When studying historical forest cover, earlier literature traditionally uses sources from two distinct periods, the medieval and the Early Modern age. Medieval narrative sources, authored mostly by foreign travelers, describe the Carpathian Basin as an area rich in woodlands. These assumptions, however, should be discussed in their respective contexts. Most of these chroniclers came from Western Europe - i.e. from the northern part of present-day France, the Low Countries or the German-speaking areas. Compared to these regions, the Carpathian Basin was certainly highly forested. However, similar sources from the Early Modern period speak of large wastelands, probably not irrespective of their narratives focusing on the vicious acts of the Ottomans. From the 18th century onwards there is a statistically significant number of different sources that testify to the scarcity of forested areas in the Great Hungarian Plain. This, combined with the anti-Ottoman sentiments, led scholars to hypothesize that Ottoman presence can be blamed for the loss of woodlands. Several sources point to a change in the functions of forests, but the archival evidence and the published sources are insufficient to estimate the extent of the forest cover before or after the Ottoman conquest, and therefore these differences are difficult to explore. This article cannot claim to fully re-evaluate the landscape historical or even forest historical consequences of the expansion of the Ottoman Empire to the Carpathian Basin. What is done here, however, is a study of the possible impact of one of the presumably most significant forms of wood exploitation in the period, i.e., the construction of wood and earth fortifications along the frontier. The whole region of Transdanubia is discussed here, with special regard to the areas that were most severely affected by the Ottoman wars and the construction of wood and earth fortifications along the front line. The study of this area may be revealing not only for the central plain, but

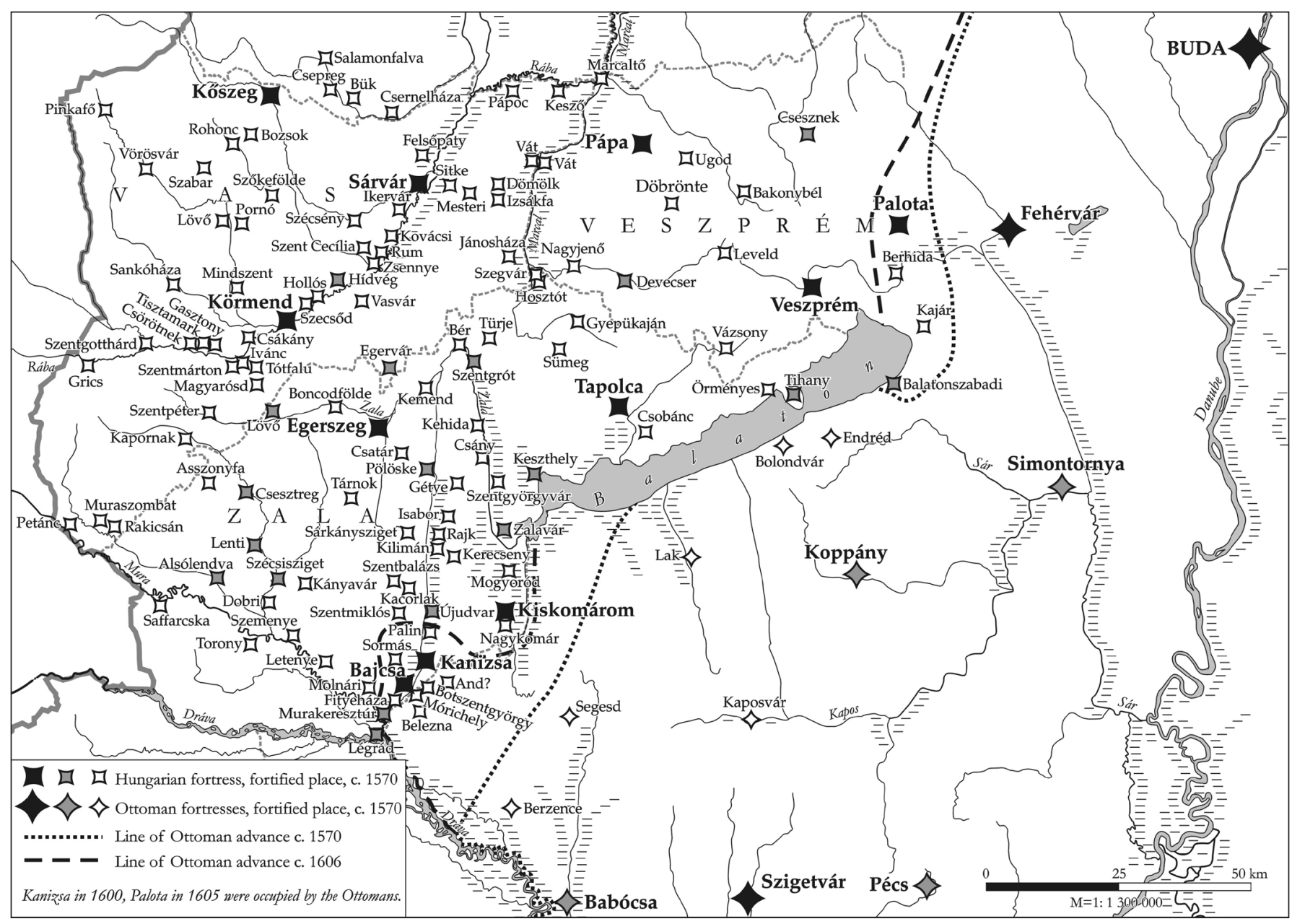

Fig. 1. Hungarian and Ottoman fortifications in southern and western Transdanubia (drawing by Béla Nagy) 
András Vadas $\bullet$ To the Last Tree Standing? Ottoman-Hungarian Wars and Forests in Transdanubia

also for the northern edges of the Great Hungarian Plain, where forests were probably used in similar ways in in the sixteenth and seventeenth century.

\section{MILITARY DEFENSE AND THE EXPLOITATION OF FOREST RESOURCES IN TRANSDANUBIA IN THE 16TH-17TH CENTURIES}

When studying the impact of the Ottoman conquest on the forests of the Carpathian Basin, one of the most frequently emphasized factor is the wood consumption of the border fortresses, for the construction and maintenance of the wood and earth fortifications. Until recently it was accepted in the scholarship that the construction and frequent rebuilding of these fortifications necessitated an increased exploitation of forest resources during the ca. 150 year-long Ottoman presence, and that this may have been the major cause behind deforestation at the time. Recently, however, several scholars expressed caution and hypothesized a less dramatic deforestation (RÁcz, 2013, Ágoston, 2009; Szabó 2009). In order to assess the role of such construction works in the decrease of the forest cover, I provide a very rough estimate of their wood consumption in the following. I discuss how much timber was necessary for the construction of the wooden fortifications in Transdanubia - these were built partly of stone, partly of wood, and smaller fortresses were built solely of timber. Quantifying and comparing consumption (number of fortifications and the amount of timber needed to build and maintain them) and production (woodland area necessary to produce the given amount of timber) allows for a rough estimation.

There are two basic types of sources, written and archaeological, on the use of timber in these fortresses. In the written sources one finds scattered data about acquisition, descriptions of fortresses, as well as pictorial and cartographic evidence. These sources were studied mostly in the context of individual fortifications and not even a systematic collection of the pictorial evidence has been done so far. The potentials of using archaeological data were shown by a relatively recent study by Gyöngyi Kovács and Pál Sümegi. By studying the archaeological traces - mostly post holes - of two fully destroyed fortifications, they managed to give a relatively precise estimate of the number of stakes that were used for the constructions of the building complexes (Kovács \& SüMEgi 2011). I believe that with some cautions this is the best way to understand the

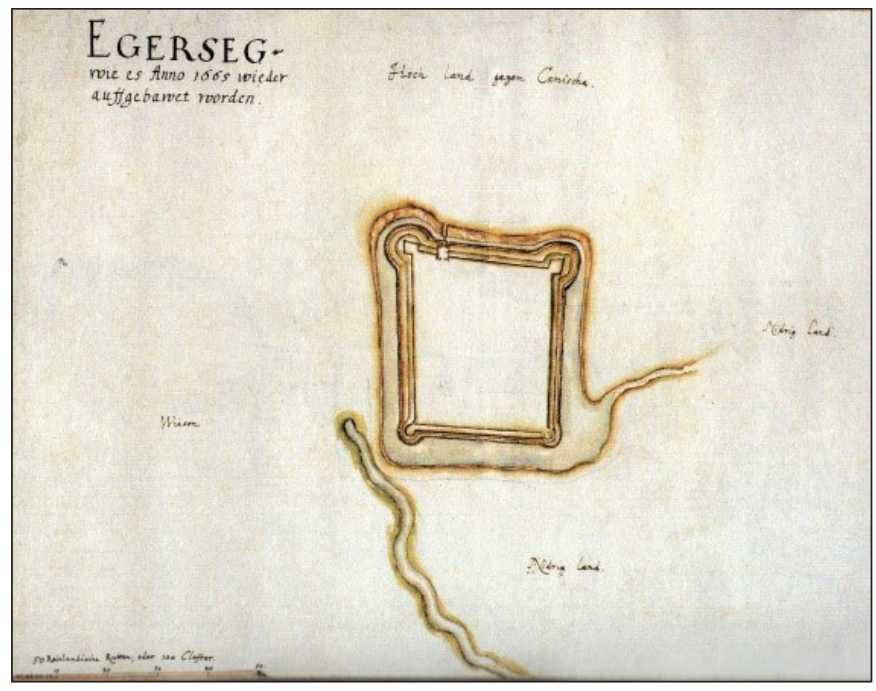

Fig. 2. Drawing of the palisade fort of Egeszerszeg (Jacob von Holst, 1665).

Source: https://gocsejimuzeum.hu/sites/default/files/kepek/ galeriak/szertar/var 05.jpg (Accessed: 17 June 2020)

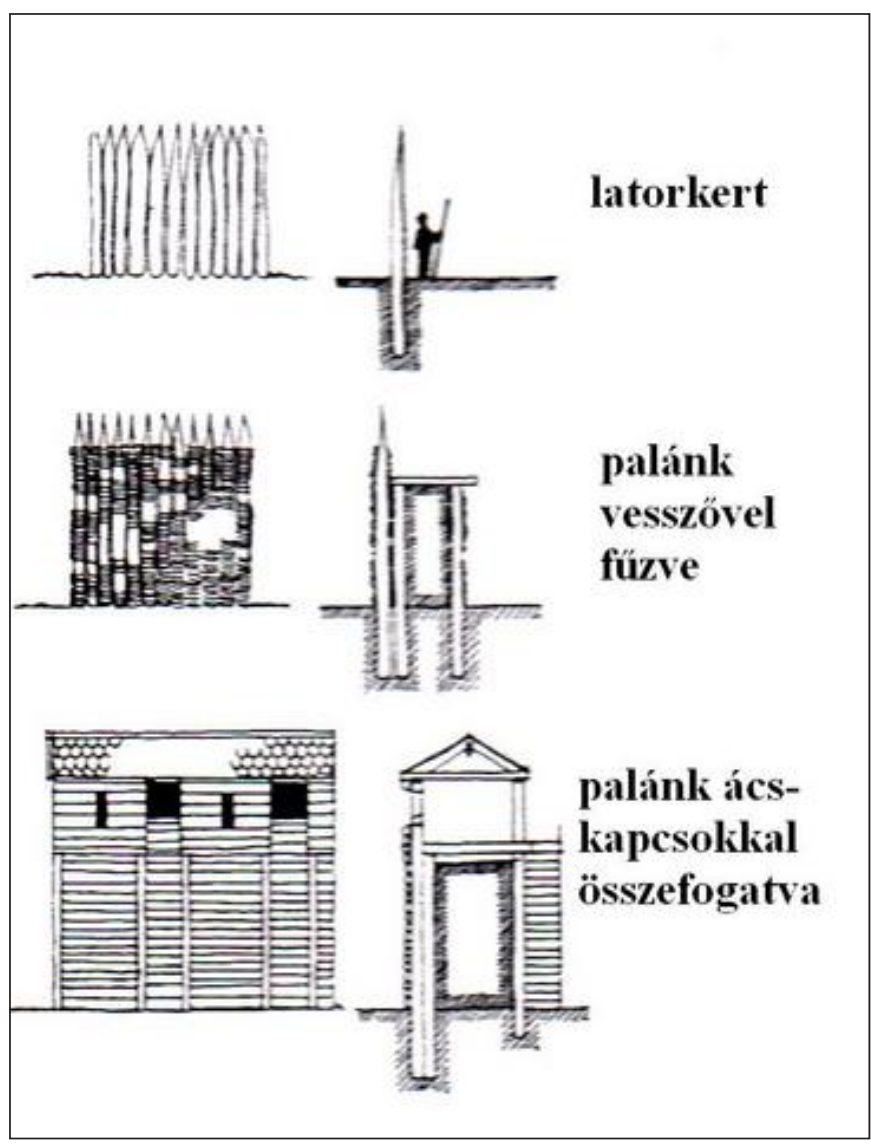

Fig. 3. Ottoman-period fortification types mentioned in the study (after GERÖ, 1977, 337) 
András Vadas • To the Last Tree Standing? Ottoman-Hungarian Wars and Forests in Transdanubia

environmental pressure on forests caused by Early Modern fortification work. To assess the dimensions of these construction works, at least a rough estimation of the number of fortifications at Early Modern Transdanubia is needed, including their sizes and structures.

For the present analysis, the most important aspect is the structure of the fortification walls. It was not only the construction of walls that required a considerable amount of timber; to surround manor houses and watchtowers and to build fortifications predominantly of wood in a short period of time were typical of the Ottoman war period. Scholarship usually differentiates between three types of fortification walls (TAKÁts 1907; 1915-1917, II, 1-132; Pataki 1937; Tolnai 2011, 15-16). The simplest type is the so-called latorkert. This was basically a fence built of stakes driven deep into the ground close to each other, to which wattles were attached. Building these required only a modest technological expertise. This type was frequently used to fortify small watchtowers and posts (so-called górés) as well as to surround unfortified manor houses and, in some cases, churches, or as second or third fortification lines around major fortresses. Compared to its limited potential in defense, its construction required significant amounts of wood, as the stakes were driven next to each other with only small gaps in-between (TOLNAI 2011). The other two, more sophisticated types of walls were formed by two lines of stakes that ran parallel. While in the case of the latorkert-type walls the stakes were usually placed ca. $10 \mathrm{~cm}$ from each other, in the two other types their distance was multiple times as much. In one of these more complex types the stakes were attached to each other by wattles, similarly to the latorkert type. The best quality wattle was made of willow, however where it was not available, almost every species of tree was used. The most important difference between simple fences and these fortification walls was that earth was piled between the two lines of stakes attached by wattles, and the wattles were strengthened with mud. At the most elaborate earth and wood fortifications, the stakes were fastened to each other also by iron clasps in addition to the wattles. If the two lines of stakes were relatively far from each other - in some cases, even meters -, huge amounts of earth and mud was needed for the construction. In order to give an estimate of the wood consumption of the fortification systems on either side of the border, one needs a database that lists the fortresses in Transdanubia. To do so, at least some data are necessary, including their sizes, shapes, and the structure of their walls. It is important to emphasize that the timber need of the buildings within the walled areas are not discussed here. Although these are also an important factor, it is even less likely to find relevant data on these constructions and in many cases there were stone or brick buildings within the wooden fortifications. However, it seems that the walls were the largest consumers of wood, and not the buildings inside. This is supported by the fact that the timber built into the garrisons and castle building structures had to be replaced less frequently than the stakes poled deep down into the wet soil. Of course, in many cases not even these outer walls were built solely of wood. There are several brick or stone walls or sections of walls built of these more expensive and lasting materials (e.g. PÁLfFY, 1995 or VADAS, 2013). Finally, another problem needs to be addressed here: entirely different amounts of wood was used for a fortification that functioned for a few years, than for those that were used during the whole Ottoman period. The wooden parts of the walls had to be replaced regularly, partly because of the natural decay of the wood and partly due to different natural phenomena and sieges.

Data is unavailable on the parameters, main building material or wall structure of every single fortification at Transdanubia. In some cases, however, either based on written evidence or archaeological data, there is a chance to reconstruct the

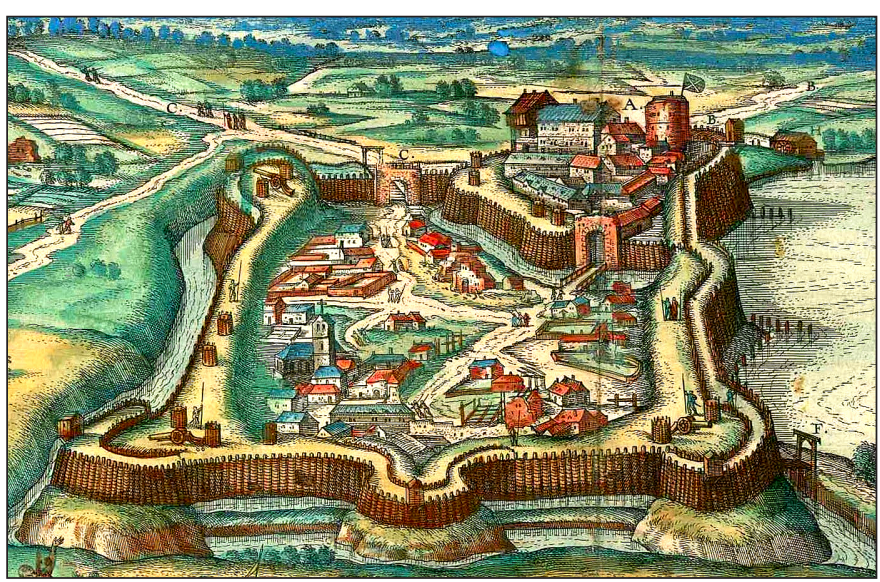

Fig. 4. The view of Pápa, with the palisade surrounding the town. Georg Braun and Franz Hogenberg, Civitates Orbis Terrarum. VI. Cologne, 1617. 35. (etching by Georg Hoefnagel)

Source: https://commons.wikimedia. org/wiki/File:P\%C3\%Alpa engraving after Hufnagel 1617 colorized.jpg (Accessed: 16 June 2020) 
András Vadas $\bullet$ To the Last Tree Standing? Ottoman-Hungarian Wars and Forests in Transdanubia

main features of different fortresses. Not even the exact location is known for several small watchtowers and other fortifications. With most of the fortifications it proved to be easier to calculate how long they functioned. In some cases, there is evidence of major rebuilding works or extensions at different fortresses, however, for some of these there is no other information than a single reference from the sixteenth century. All these methodological problems make any calculation of the wood use of the fortification works only an educated guess. The primary goal here, however, is not to offer an exact number, but to give a rough estimate of the scale of the wood consumption, and assess if these fortresses indeed may have been driving factors in deforestation, as is suggested by most of the literature. By doing so, it may become more clear whether the Ottoman conquest and wars were the main factors in the change of the forest cover in the central part of the Carpathian Basin.

The majority of the data on Ottoman fortifications come from the important handbook by Klára Hegyi (HegYi, 2007), while the data on the Hungarian side was gathered from military history handbooks, castle cadasters and archaeological reports of the excavation of some of the fortifications (PÁLFFY, 1995, 2000, TolnAI, 2011, etc.). At present, there is more than 300 fortifications in the database, including fortified manor houses, fortresses, as well as small watchtowers. Gathering all the above-mentioned data for each of these buildings would require years of work, therefore I had to make certain generalizations. The first of these was to make a rough estimate of the perimeter of the small, the mid-size, and the larger wood and earth fortifications. Then, I had to assess how much wood was necessary to build one meter of wall for the different types of fortifications, and finally, to estimate how often the stakes were replaced. In some cases, there are relatively useful data at hand, such as castle descriptions, maps, or views. However, this only applies to a small number of the fortifications. At recent excavations, fortification walls of buildings from this period were uncovered; the post holes of the stakes provide the most precise data on the structures. These excavations gave information not only on the size of these fortresses, but also on the amount of wood used for a meter of different types of walls. For most of these fortifications, however, there is a complete lack of information on their size. In such cases I had no other choice than to estimate the size based on the garrisons they housed, as this is the only information available for most of the fortifications. Three categories were created, smaller watchtowers and castles ( 1 to 49 guards), mid-sized fortifications (50 to 199 guards), and major fortresses (housing 200 or more guards). In order to avoid underestimating the importance of re-building, I calculated with ten-year cycles, meaning that within that timeframe every single stake was replaced by a new one. Of course, this practically means that stakes standing in a muddy area were replaced every or every few years, while others, as the archaeological data testifies, were never replaced during the Ottoman period (ToIfL, 2002). This calculation probably overestimates the frequency of re-building and the replacing of stakes; however, it is better to calculate with the upper margin to gain a more reliable result.

The next step was to calculate how long the different fortifications functioned. Some fortresses changed hands multiple times, other were only

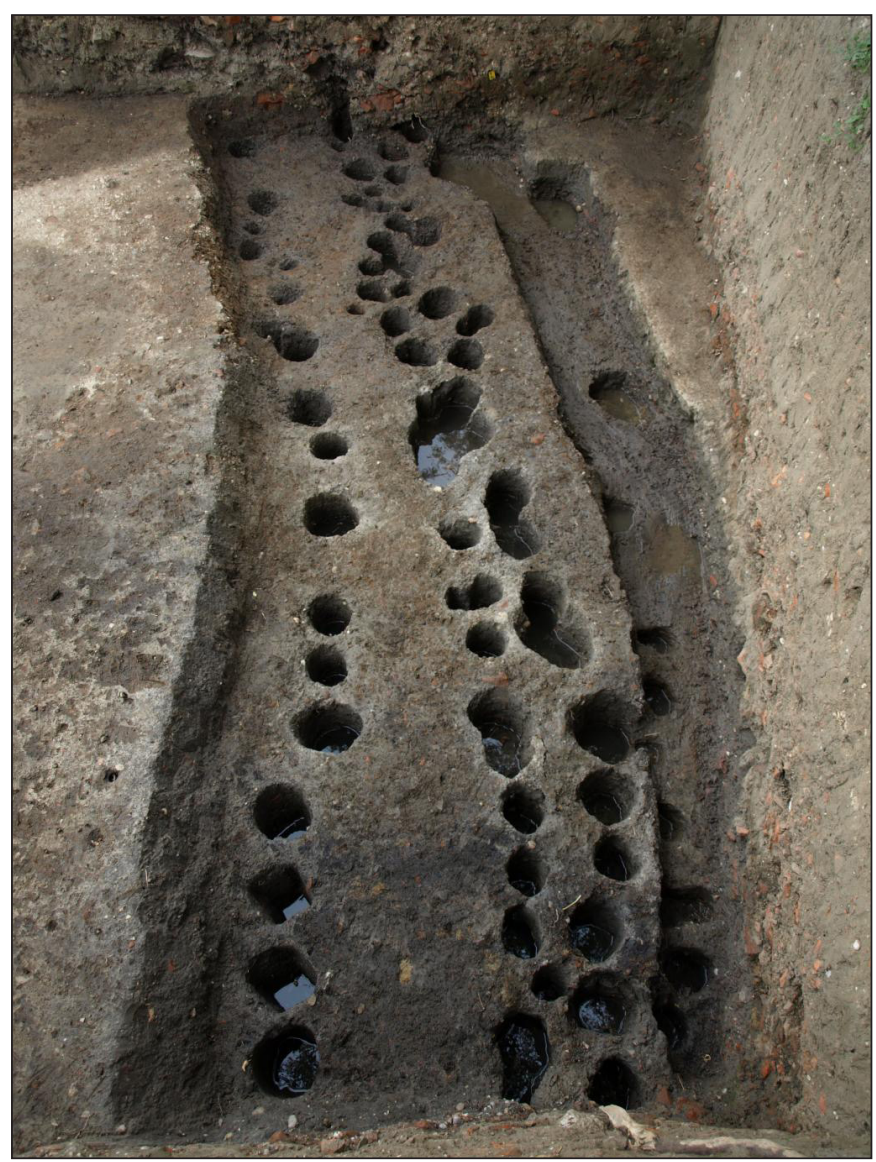

Fig. 5. Post holes of the palisade in the Ottoman-period fort of Zalalövö, as seen at the 2014 excavations.

Source: https://gocsejimuzeum.hu/sites/default/files/kepek/ galeriak/gm hirek/p8256153.jpg (Accesed: 15 June 2020) 
functioning for a few years. This is important mostly because of the calculations of stake replacement and other forms of rebuilding. Where there was information in the literature, I used these to determine how long the fortifications functioned. When only the beginning or the end date of their existence was known, I counted with an uninterrupted functioning before or after the respective date in the period between 1540 and 1690. This again is probably an exaggeration, but for the same reason as above, this allows a better estimation.

With these simplifications, only an estimation is possible with a large margin of error regarding the timber need of the fortifications in Transdanubia. Consequently, the goal was to provide an educated guess on the size of the forests that were necessary to deliver the timber needed for construction and re-building. The estimate by no ways allows a nuanced analysis of the change in the forest cover of Transdanubia but may help to understand whether the fortification works can be blamed for deforestation, and whether it indeed meant large-scale wood consumption.

The database gathered contains 220 fortifications on the Hungarian and 95 on the Ottoman side. Due to the nature of the Ottoman source material, that dataset may be more complete than the Hungarian one, where dozens of small watchtowers, fortified churches or other buildings must have remained unregistered. Not only fortifications, but in many cases towns and even villages were surrounded by similar walls, that were never systematically researched. There were numerous settlements with stone or wooden palisades, dating to the Middle Ages, which were extended and reinforced - partly with wood - when people faced the Ottoman threat in the Early Modern period. Moreover, not only the wooden fortifications, but also the stone ones needed timber. However, the goal was to gain a better understanding of new forms of wood consumption.

According to this calculation methods, in order to build the ca. 320 fortifications in Transdanubia included in the database at this point, ca. 3600 trees were needed yearly on the Ottoman, while 6300 on the Hungarian/Habsburg side on average to meet the need for fortification walls. That means twice as many stakes, i.e. 7200 and 12,600, respectively. This, for the roughly 150 years of the Ottoman presence, means a total of 540,000 ad 938,000 trees. However, some things must be noted. First, as it was referred to above, the numbers only apply to the stakes themselves, neither the timber needed for the buildings within the walled areas, nor the material used for attaching the stakes, or strengthening the earthworks is included. Second, it is important to note that the intensity of fortification building changed with time. While many new fortifications were erected in the 1540s, and even more in the 1550s in Transdanubia, from the 1570s onwards, when the frontier defense system stabilized both on the Hungarian and the Ottoman sides, fortification building became less important. Until the 1570 s probably more than 10,000 trees were felled annually for these purposes, while in the $1670 \mathrm{~s}$, for instance, there was probably a limited demand for wood (PÁlfFY, 2000).

The most important question that needs to be addressed here is the extent of the area that was necessary to harvest these 10,000 trees annually. Research is cautious with providing an estimate of the medieval productivity of forests, however, there are detailed datasets for the 19th- and 20th-century situation, which, are applicable to pre-modern times with some restrictions. In modern forestry, thousands of trees are planted on a hectare of land, only the fastest growing ones of which are left to develop; in case of the most frequent oak forests, the trees are ca. 4 meters from each other. This is particularly important as it was oak, and less frequently fir, which was used for stakes built into the fortification walls in the Ottoman period. Assuming a less intensive medieval and Early Modern forest management, i.e. counting with trees standing 5 meters from each other, a hectare of forest had ca. 400 standing trees. This means that fulfilling the average wood demand of the wood and earth fortifications of Transdanubia would not have required more than 25 hectares of forests to be cut annually. As mostly oak trees with a diameter of 20-30 cm were used, they were felled around the age of 50 years. This means, that one can count with three cutting cycles in forests reserved for felling trees to provide stakes during the Ottoman period. This means that altogether $1250([25 \times 150] / 3)$ that is $12,5 \mathrm{~km}^{2}$ of forests had to be constantly managed in Transdanubia to provide the necessary number of stakes. It also makes sense to calculate the required area if one counts with coppice forests rather than 
high forests. In this management system, timber was combined with firewood, and the smaller branches that sprout either directly from the roots or from the trunks were cut back on a regular basis, as these proved to be well suited as firewood. Stakes were also harvested from coppice forests, however, in much smaller quantities than from high forests. Although historical sources refer to a wide range of numbers (Szabó, 2010), based on modern forestry analogies one can count with ca. 35 trees from a hectare. This method would therefore have required 14,000 hectares, that is, $140 \mathrm{~km}^{2}$. It must be kept in mind, however, that in that case the primary use of the woodland would have been for firewood, and the stakes would have only been side products of the coppice forest.

These numbers are remarkably low. One may assume that they are heavily underestimated - which, for the above-mentioned reasons, is possible - and in fact, ten times as much forest had to be used to build the fortifications in question, but even then, a relatively small proportion of the forests would have been used to build and re-build the wood and earth fortifications. This is true even for the counties in Western Transdanubia that had the most fortifications. This is certainly surprising in the light of the existing literature which still attributes primary importance to the construction of fortifications in deforestation, both on a local and a regional scale.

\section{CONCLUSIONS AND OUTLOOK}

The article discussed whether the fortification building wave associated with the Ottoman presence put a significant pressure on the forests of the frontier zone of Transdanubia in general. In contrast to the general view, the results suggest that its importance was only secondary. When arguing for the importance of fortification building in deforestation, scholars keep quoting the sources that refer to Early Modern instructive documents on the protection of forests. These have been interpreted as evidence of a decrease in available forest resources. However, most of these sources, including many of the instructions published in the Cartulary of Hungarian Forestry (Magyar erdészeti oklevéltár), say nothing about the scarcity of forests, firewood or timber. These documents rather served as regulations to facilitate a more transparent forest use, and do not suggest a shortage of resources. The mandates issued by the Habsburg emperors point to an increasingly sophisticated forest management system not only in the Kingdom of Hungary but also in other parts of the Habsburg Empire. Furthermore, this is not specific to Central Europe, but research recently pointed to similar developments in a number of Early Modern states. In the Venetian Republic, the beginnings of a conscious forest management date back to the medieval period, but in the 16th and 17th centuries, the French Kingdom, the Holy Roman Empire, as well as the Spanish Empire went through similar changes. Finally, and it is crucial for the present paper, recent works suggested a conscious - so to say, sustainable - forest management in the Ottoman Empire as well. In sum, it seems that the different polities, recognizing the strategic importance of this resource, tried to avoid the shortage of raw material, which would potentially threaten the functioning the economies, or even the military defense. This further strengthens the hypothesis that the Ottoman presence was only less directly behind the change in the woodlands in the Early Modern period. If they planned to stay for long in the Carpathian Basin, just as the Hungarians, it was not in their interest to exhaust forest resources in the areas they controlled.

The loss of forested areas, recurrently associated with the Ottoman Empire, fitted the narrative of a general decline; however, in the interwar period another view was put forward, stating that the forests appeared as a result of the landscape growing wild. This theory was also emphasized in the context of Transdanubia, where, according to some scholars, the significant population loss in went hand in hand with re-forestation. Therefore, it is also possible that the overall balance of forest cover in the Ottoman period was rather positive than negative. This is certainly not so for the 18th century, a period seen as the re-building of the country. Just as in the famous Hungarian folk song in which a stork's leg was cut by a Turkish boy, associating the Ottoman wars with the loss of woodland in the Carpathian Basin may rather be a result of a collective memory about the Ottoman period than an actual development. 
András Vadas • To the Last Tree Standing? Ottoman-Hungarian Wars and Forests in Transdanubia

BIBLIOGRAPHY

Ágoston, G. (2009). Where Environmental and Frontier Studies Meet:Rivers, Forests, Marshes and Forts along the Ottoman-Hapsburg Frontier in Hungary. In A. C. S. Peacock (ed.), The Frontiers of the Ottoman World (pp. 57-79). Oxford: Oxford University Press. https://doi.org/10.5871/bacad/9780197264423.001.0001

Appuhn, K. R. (2009). A Forest on the Sea: Environmental Expertise in Renaissance Venice. Baltimore: The Johns Hopkins University Press.

First Military Survey. Online database. www.mapire.eu (Accessed: 1 May 2018.)

Gerö, L. (1975). A török elleni harcokban átépített, vagy újonnan épített bástyás várak kialakulása [How the fortresses with bastions, erected or re-built during the Ottoman wars came to be]. In L. Gerö (ed.), Várépitészetünk (pp. 325-344). Budapest: Müszaki Kiadó.

Hegyi, K. (2007). A török hódoltság várai és várkatonasága, [Forts and fortress guards during the Ottoman conquest] vols. I-III. Budapest: História - MTA Történettudományi Intézet.

Kovács, Gy. \& Sümegi, P. (2011). Palánkvárak, fák, erdők. Régészeti és környezettörténeti adatok a török kori palánkvárak faanyag-felhasználásához [Palisade forts, trees, woodlands. Archaeological and environmental historical data on the wood use of Ottoman-period palisade forts]. In Gy. Terei et al. (eds), Várak nyomában. Tanulmányok a 60 éves Feld István tiszteletére (pp. 113-120). Budapest: Castrum Bene Egyesület.

Matteson, K. (2015). Forests in Revolutionary France: Conservation, Community, and Conflict 1669-1848. New York: Cambridge University Press. https://doi.org/10.1017/CBO9781107338197.

Mikhail, A. (2013). Nature and Empire in Ottoman Egypt: An Environmental history. New York: Cambridge University Press. https://doi.org/10.1017/CB09780511977220

Pálffy, G. (1995). A magyarországi és délvidéki végvárrendszer 1576. és 1582. évi jegyzékei [Documents on frontier forts in Hungary and the Délvidék region from 1576 and 1582]. Hadtörténelmi Közlemények $108,114-185$

Pálffy, G. (2000). The Origins and Development of the Border Defence System Against the Ottoman Empire in Hungary (Up to the Early Eighteenth Century). In: G. Dávid \& P. Fodor (eds.), Ottomans, Hungarians, and Habsburgs in Central Europe: The Military Confines in the Era of the Ottoman Conquest (pp. 3-69). Leiden, Boston, \& Köln: Brill.

Pataki, V. (1931). A XVI. századi várépítés Magyarországon [16th-century fortress building in Hungary]. A Bécsi Magyar Történeti Intézet Évkönyve 1, 98-133.

Rácz, L. (2013). The Steppe to Europe. An Environmental History of Hungary in the Traditional Age. Cambridge: White Horse Press.

Szabó, P. (2008). Changes in Woodland Cover in the Carpathian Basin. In P. Szabó \& R. Hédl (eds), Human Nature. Studies in Historical Ecology and Environmental History (pp. 106-115) Brno: Institute of Botany of the ASC. https://doi.org/10.1016/i.foreco.2009.11.026 
András Vadas $\bullet$ To the Last Tree Standing? Ottoman-Hungarian Wars and Forests in Transdanubia

Szabó, P. (2009). Erdők a kora újkorban: történelem, régészet, ökológia [Forests in the Early Modern period: History, archaeology, ecology]. In M. Kázmér (ed.), Környezettörténet. Az utóbbi 500 év környezeti eseményei történeti és természettudományi források tükrében (pp. 137-156). Budapest: Hantken.

Szabó, P. (2010). Driving Forces of Stability and Change in Woodland Structure: ACase-Study from the Czech Lowlands. Forest Ecology and Management 259, 650-656. https://doi.org/10.1016/j.foreco.2009.11.026

Takáts, S. (1907). A magyar vár [The Hungarian fort]. Századok 41, 726-741; 815-837.

Takáts, S. (1915-1917). Rajzok a török világból [Scenes from the Ottoman world], I-IV. Budapest: Magyar Tudományos Akadémia.

Toifl, L. (2002). Bajcsavár története a stájer levéltári források alapján [The history of Weitschawar based on archival material from Styria]. In Gy. Kovács (ed.), Weitschawar/Bajcsa-Vár. Egy stájer erödítmény Magyarországon a 16. század második felében (pp. 28-34). Zalaegerszeg: Zala Megyei Múzeumok Igazgatósága.

Tolnai, G. (2011). Palánkvárak Magyarországon [Palisade forts in Hungary]. Budapest: Martin Opitz.

Vadas, A. (2013). Körmend és a vizek. Egy település és környezete a kora újkorban [Körmend and the waters. A settlement and its environment in the Early Modern period]. Budapest: Történelemtudományok Doktori Iskola.

Vági, I. (1934). Van-e hazánkban ezeréves puszta, vagy azt a török hódoltság okozta. Megváltozott-e a Nagy-Alföld éghajlata a török hódoltság miatt aszályosabb irányban, továbbá a talajok is alig javíthatóan megromlottak-e a valóságban [Is there a thousand-year-old wasteland in our country or is it a result of the Ottoman conquest. Did the climate of the Great Plain become drier and the soil barren in this period?]. Erdészeti Lapok 73, 670-682.

Wallner, E. (1941). A Bakony erdőtakarójának átalakulása a XVIII. század végéig [Changes in the forest cover of the Bakony until the end of the 18th century]. Földrajzi közlemények 69, 1-29.

Wallner, E. (1942). A Bakony erdőtakarójának pusztulása a XIX. században [Devastation of the forest cover of the Bakony in the 19th century]. Földrajzi közlemények 70, 32-42.

Warde, P. (2010). Ecology, Economy and State Formation in Early Modern Germany. Cambridge: Cambridge University Press. https://doi.org/10.1017/CBO9780511497230

Warde, P. (2018). The Invention of Sustainability: Nature and Destiny, c. 1500-1870. Cambridge: Cambridge University Press. https://doi.org/10.1017/9781316584767

Weidlein, J. (1935). A dủlőnévkutatás történeti vonatkozásai [Historical aspects of the research into hills' names]. Századok 69, 665-692.

Wing, J. T. (2015). Roots of Empire: Forests and State Power in Early Modern Spain, c. 1500-1750. Leiden, \& Boston: Brill. https://doi.org/10.1163/9789004261372 